\title{
Communication
}

\section{Preliminary Evaluation of Enteric Viruses in Bottled Mineral Water Commercialized in Brazil}

\section{Vivian Rodrigues dos Santos, Caroline Rigotto *, Rodrigo Staggemeier, Andréia Dalla Vecchia, Andréia Henzel and Fernando Rosado Spilki}

Laboratório de Microbiologia Molecular, Instituto de Ciências da Saúde, Universidade Feevale, Prédio Vermelho $2^{\circ}$ Andar, Sala 205 RS 239, n² 2755, Vila Nova, 93352-000, Novo Hamburgo, RS, Brazil; E-Mails: vivianxz@yahoo.com.br (V.R.S.); rstaggemeier@gmail.com (R.S.); andreiavecchia@gmail.com (A.D.V.); henzelvet@gmail.com (A.H.); fernandors@ feevale.br (F.R.S.)

* Author to whom correspondence should be addressed; E-Mail: rigottocarol@ gmail.com; Tel.: +55-51-3586-8800-9043.

Academic Editor: Abua Ikem

Received: 9 May 2015 / Accepted: 17 July 2015 / Published: 23 July 2015

\begin{abstract}
In Brazil, mineral water is widely consumed and as of yet there have been no studies done in the country that aim to detect enteric viruses in this water source. The aim of this study was to analyze the presence of the human adenovirus (HAdV), the human rotavirus genogroup A (GARV) and the human enterovirus (hEV) in mineral water samples from six different brands that are commercialized in southern Brazil, using molecular techniques and comparing the results with bacterial indicators. Samples of $1.5 \mathrm{~L}$ and $500 \mathrm{~mL}$ were analyzed for viruses through PCR and total and thermotolerant coliforms. Additionally, heterotrophic bacteria were assayed using a commercial kit. The most prevalent virus was adenovirus $(32.5 \%)$ followed by rotavirus $(25 \%)$ and enterovirus $(17.5 \%)$. Total and thermotolerant coliforms were absent in all samples and only three samples out of the 60 analyzed presented heterotrophic bacteria contamination. We conclude that, following the example taken into consideration regarding the public supply of drinking water, stricter measures for microbiological control should also be applied to mineral water so that this actually becomes a safer alternative.
\end{abstract}

Keywords: enteric viruses; HAdV; hEV; GARV; mineral water 


\section{Introduction}

Water quality is essential for human health and should be safely available for the population. Brazil is the sixth largest consumer of mineral bottled water worldwide, with a per capita consumption of 13 L/year (ABINAM - Brazilian Association of Mineral Water Industries) [1]. This may be due to the nation's increasing standards of living and the population' general perception that bottled mineral water is the healthier and safer option for consumption when compared with other sources. Queiroz et al. (2013) [2] suggested that bottled water might have the same or worse bacteriological and chemical quality as tap water, concluding that bottled water is not better than tap water when considering health benefits. Santana et al. (2003) [3] have demonstrated that up to $25 \%$ of commercialized mineral water studied in Brazil did not meet standard regulation. The presence of microbial contaminants depends on source characteristics, bottling methods, asepsis of the packaging material and product storage. The problem is exacerbated by the fact that $64 \%$ of mineral water in Brazil is distributed to the final consumer in reusable containers with a 20 L capacity or more (ABINAM) [1]. In Brazil, ordinance No. 274/2005 [4] from the Ministry of Health regulates the microbial quality of natural mineral water and requires that only fecal coliforms and thermotolerant bacteria be tested for. Among the enteric viruses, three of the ones that are most studied as environmental contaminants are the adenoviruses (HAdV, Adenoviridae family, Mastadenovirus genus, double-stranded DNA), enteroviruses (hEV, Picornaviridae family, Enterovirus genus, single-stranded RNA) and rotaviruses (GARV, Reoviridae family, Rotavirus genus) (Fong and Lipp 2005 [5]). These agents are often transmitted by the fecal-oral route, which is associated with gastroenteritis, especially in human and animals (Ahmad et al. 2009 [6]). Despite the health impacts caused by outbreaks of these viruses, monitoring and reporting their presence in drinking water, sewage effluents, and recreational waters is not mandatory in many countries, including Brazil. Studies in Brazil aimed at detecting enteric viruses in mineral water have not been carried out yet, even though the presence of these microorganisms in this product has been already reported (Gassilloud et al. 2003 [7]; Leclerc and Moreau 2002 [8]). In this context, the goal of the current study was to examine mineral water for the presence of the enteric viruses HAdV, hEV and GARV in mineral water and the possible sources of transmission.

\section{Material and Methods}

\subsection{Mineral Waters}

Six Brazilian brands of still water, bottled in polyethylene bottles, were selected for this study. Forty (40) samples of $1.5 \mathrm{~L}$ and $500 \mathrm{~mL}$ bottles (20 from each volume) of each brand were bought at a local grocery store. An additional twenty (20) mineral water samples were collected aseptically in $500 \mathrm{~mL}$ sterile glass bottles from $20 \mathrm{~L}$ reusable containers from 5 different departments located at the Feevale University campus during the months of March, June, September and November of 2011. The water containers were available for students and staff and were all from the same supplier. All sampled waters were still within expiration date. According to Brazilian legislation-RDC No. 274/2005 [4] —one sample from every five samples from the same lot (according to labels) was chosen for analysis. Samples were stored in darkness at $4{ }^{\circ} \mathrm{C}$ for no more than two days. 


\subsection{Sample Concentration}

Mineral water samples $(500 \mathrm{~mL})$ were concentrated using an adsorption-elution method with negatively charged membranes (HA, Millipore, USA), based on the method from Katayama et al. (2002) [9] with modifications (Vecchia et al., 2012 [10]). The resulting concentrates were stored at $-80{ }^{\circ} \mathrm{C}$ until further processing was done.

\subsection{Viral Nucleic Acid Extraction}

Viral nucleic acids were extracted from $400 \mu \mathrm{L}$ of the concentrated sample using the $\mathrm{RTP}^{\circledR}$ DNA/RNA Virus Mini Kit (Invitek, Berlin, Germany), according to the manufacturer's instructions. The nucleic acids obtained were kept at $-80{ }^{\circ} \mathrm{C}$ until further analysis was done.

\subsection{Polymerase Chain Reaction Assays for Detecting Virus Genomes}

In order to amplify the hEV and GARV genomes, a prior cDNA synthesis step was carried out using the High Capacity cDNA Reverse Transcription ${ }^{\mathrm{TM}}$ commercial kit (Applied Biosystems $^{\mathrm{TM}}$, Carlsbad, CA, USA), with random primers and RNAse Inhibitor (Applied Biosciences ${ }^{\mathrm{TM}}$, USA), following the manufacturer's instructions. All PCR reactions were performed as previously described (de Oliveira et al. 2012 [11]; Dalla Vecchia et al. 2015 [12]) using primers designed to anneal in the highly conserved regions of each viral genome. After the reactions, PCR products were stained with a nontoxic fluorescent dye, SYBR ${ }^{\circledR}$ SAFE DNA Gel Stain (Invitrogen ${ }^{\mathrm{TM}}$, Waltham, MA, USA), analyzed by electrophoresis on $2 \%(\mathrm{w} / \mathrm{v})$ agarose gel and visualized under ultraviolet (UV) light. To determine the analytical sensitivity of the assays, 10-fold serial dilutions of each DNA/RNA standard were employed. EV-PCR has shown to detect a minimum of 0.316 tissue culture infective doses (TCID50) of experimentally contaminated water. For the AdV values were $6.2 \times 10^{1} \mathrm{GC}$ (qPCR) and $0.562 \mathrm{TCID}_{50}$ (PCR). For GARV, the amount of DNA used for amplification was measured by comparison with Low Mass DNA ladder (Invitrogen ${ }^{\mathrm{TM}}$, USA) and the detection limit determined as $200 \mathrm{ng}$ per sample.

Wolf et al. (2010) [13] have described the primers used for HAdV quantification by qPCR and Dalla Vecchia et al. (2015) [12] have standardized and described the reaction. The qPCR was carried out in iQ5 Real-Time PCR Detection System thermocycler (Bio-Rad Laboratories, Hercules, CA, USA) with $\mathrm{iQ}^{\mathrm{TM}} 5$ optical system software, version 2.1. For generating standard curves, 10-fold serial dilutions of standard controls from $10^{-1}$ to $10^{-5}$ were prepared, starting at $6.01 \times 10^{7}$ genome copy $(\mathrm{gc}$ ) per reaction $(\mathrm{HAdV}-5)$ and with all standard controls and samples being run in duplicates. There were no template controls (NTC) or negative controls (virus-free water) used in the runs so as to ensure that the assay was not contaminated.

\subsection{Bacterial Analysis}

For counting the thermotolerant coliforms and total heterotrophic bacteria from the samples, we used the commercial kit AQUACULT M (Laborclin ${ }^{\circledR}$, Brazil), following manufacturer's instructions, as per Resolution RDC No. 274/2005 [4] of the Brazilian Ministry of Health (MS). 


\section{Results}

Analyses were performed on samples of mineral waters from $0.5 \mathrm{~L}$ and $1.5 \mathrm{~L}$ bottles, and $20 \mathrm{~L}$ containers. Out of the 40 samples of bottled mineral waters analyzed by conventional PCR, at least one virus was positively detected per sample (Table 1), of which $38.2 \%$ were positive for HAdV, followed by $25 \%$ for GARV and $17.5 \%$ for $\mathrm{hEV}$. In comparison with conventional PCR, the analysis of HAdV by qPCR demonstrated a higher number of positive samples (38.2\% versus $92.3 \%$ ), with an average quantification ranging from $7.39 \times 10^{3}$ to $5.78 \times 10^{4} \mathrm{gc} / \mathrm{L}$ (Figure 1 ).

Table 1. Detection of GARV, hEV and HAdV in bottled mineral water ( 0.5 and $1.5 \mathrm{~L})$, by conventional PCR and qPCR.

\begin{tabular}{|c|c|c|c|c|}
\hline Mineral Water Brands & $\begin{array}{l}\text { GARV PCR } \\
\text { Positive \% }\end{array}$ & $\begin{array}{l}\text { hEV PCR } \\
\text { Positive \% }\end{array}$ & $\begin{array}{l}\text { HAdV PCR } \\
\text { Positive \% }\end{array}$ & $\begin{array}{c}\text { HAdV qPCR } \\
\text { Positive \% } \\
\end{array}$ \\
\hline Brand A & $80(8 / 10)$ & $0(0 / 10)$ & $10(1 / 10)$ & $90(9 / 10)$ \\
\hline Brand B & $10(1 / 10)$ & $0(0 / 10)$ & $40(2 / 5)$ & $80(8 / 10)$ \\
\hline Brand C & $0(0 / 5)$ & $20(1 / 5)$ & $40(2 / 5)$ & $100(5 / 5)$ \\
\hline Brand D & $20(1 / 5)$ & $40(2 / 5)$ & $80(4 / 5)$ & $100(5 / 5)$ \\
\hline Brand E & $0(0 / 5)$ & $80(4 / 5)$ & $20(1 / 5)$ & $100(5 / 5)$ \\
\hline Brand F & $0(0 / 5)$ & $0(0 / 5)$ & $75(3 / 4)$ & $100(4 / 4)$ \\
\hline Total & $25(10 / 40)$ & $17.5(7 / 40)$ & $38.2(13 / 34)$ & $92.3(36 / 39)$ \\
\hline
\end{tabular}

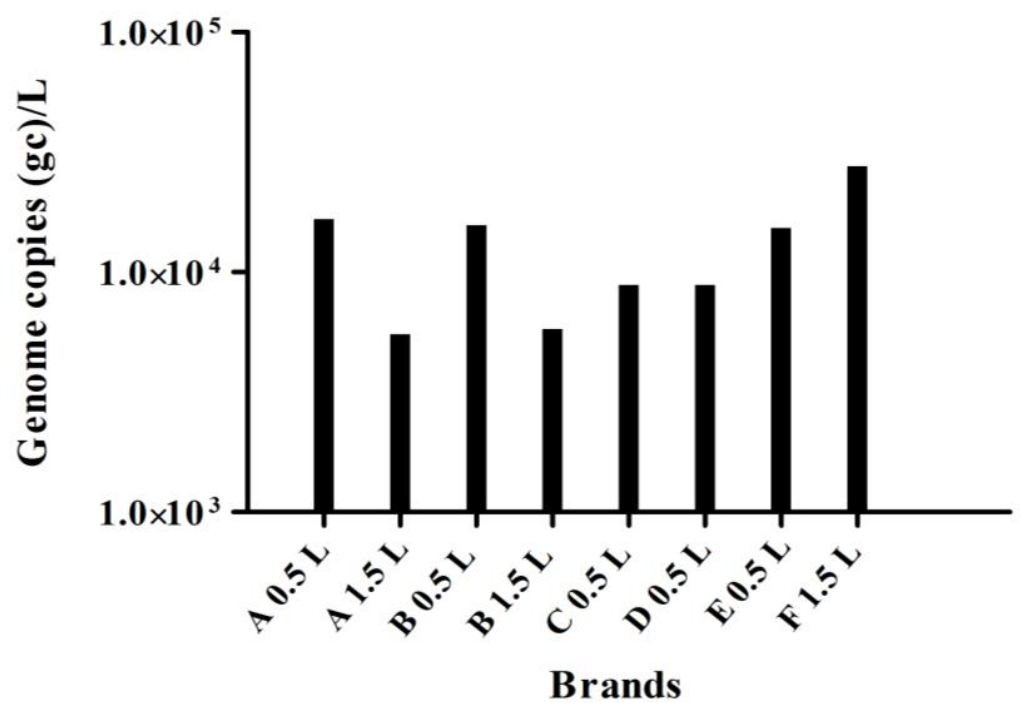

Figure 1. The average $\mathrm{HAdV}$ gc/L detected in mineral water samples (in $0.5 \mathrm{~L}$ and $1.5 \mathrm{~L}$ bottles from the same brand). Values represent the average of four samples of each brand (A-F) and volume.

The analyses of samples collected from $20 \mathrm{~L}$ containers $(n=20)$ showed that $100 \%$ were negative for $\mathrm{hEV}$ and GARV genomes by conventional PCR and $100 \%$ were positive for HAdV by qPCR, reaching values from $1.34 \times 10^{3}$ to $9.94 \times 10^{4} \mathrm{gc} / \mathrm{L}$ (Table 2 ). HAdV by conventional PCR was not tested in these samples. 
Table 2. Number of HAdV gc/L in mineral water collected from $20 \mathrm{~L}$ containers over a period of four months in 2011.

\begin{tabular}{cccccc}
\hline \multicolumn{5}{c}{ Month/Year } \\
\hline Locations & March/11 & June/11 & September/11 & November/11 & Geometric Average \\
\hline $1(n=4)$ & $1.18 \times 10^{4}$ & $8.71 \times 10^{3}$ & $6.08 \times 10^{4}$ & $2.07 \times 10^{4}$ & $2.55 \times 10^{4}$ \\
$2(n=4)$ & $3.72 \times 10^{4}$ & $1.34 \times 10^{3}$ & $5.71 \times 10^{4}$ & $3.36 \times 10^{4}$ & $3.23 \times 10^{4}$ \\
$3(n=4)$ & $2.89 \times 10^{3}$ & $6.54 \times 10^{4}$ & $3.13 \times 10^{4}$ & $2.71 \times 10^{4}$ & $3.10 \times 10^{4}$ \\
$4(n=4)$ & $9.05 \times 10^{3}$ & $1.20 \times 10^{3}$ & $6.27 \times 10^{3}$ & $9.97 \times 10^{4}$ & $2.88 \times 10^{4}$ \\
$5(n=4)$ & $7.60 \times 10^{3}$ & $5.74 \times 10^{3}$ & $6.00 \times 10^{3}$ & $8.07 \times 10^{4}$ & $4.30 \times 10^{4}$ \\
\hline
\end{tabular}

\section{Discussion}

According to Brazilian regulation of microbiological analysis, all water samples must present absence of Escherichia coli, and thermotolerant coliforms in $100 \mathrm{~mL}$. However, there is some tolerance for total coliforms, Enterococci, Pseudomonas aeruginosa, sulfite-reducing Clostridia or Clostridium perfringens, in a contaminated sample. This study followed the parameter regarding the number of $500 \mathrm{~mL}$ and 1.5 L mineral water samples collected from the same lot; total and thermotolerant coliforms were absent in the mineral water samples, although three samples were positive for heterotrophic bacteria (one $1.5 \mathrm{~L}$ bottle from brand F and two $20 \mathrm{~L}$ containers, locations 1 and 5). In previous studies in Brazil, Resende (2008) [14] and Ritter (2009) [15] analyzed bottled mineral water for the presence of coliforms and none of the samples were inconsistent with current regulations. Bacteriological analysis of bottled water has been evaluated in several studies nationwide and these findings indicate that contamination is above the levels established by regulations (Santana et al., 2003 [3]). Silva et al. (2008) [16] compared the public water supply and mineral water collected from $20 \mathrm{~L}$ water containers and concluded that the public water supply had better microbiological quality than the bottled water sold in $20 \mathrm{~L}$ containers. Several studies worldwide have also demonstrated the presence of Cryptosporidium, Pseudomonas, Aeromonas, Legionella, Penicillium, enteric viruses and pesticides, among others in mineral water samples (Rosa et al. 2008 [17]; Zeenat et al. 2009 [18]; Pontara et al. 2011 [19]; Beuret et al. 2002 [20]). In this study, we demonstrated that enteric viruses were present in six commercialized brands in Brazil, even though Brazilian legislation does not require this evaluation. In our findings, at least one virus evaluated was present per brand of bottled mineral water, with HAdV being the most prevalent, reaching a positivity rate of $92.3 \%$ (qPCR; $7.39 \times 10^{3}$ to $5.78 \times 10^{4} \mathrm{gc} / \mathrm{L}$ ). This virus was also present in $100 \%$ of the mineral water containers $(20 \mathrm{~L})$, with viral loads ranging from $1.34 \times 10^{3}$ to $9.94 \times 10^{4} \mathrm{gc} / \mathrm{L}$. HAdV is one of the main etiological agents of gastroenteritis in children under 4 years (Lee and Kim 2002 [21]) and was included in the U.S. Environmental Protection Agency's (USEPA) “Contaminant Candidate List 2" for its sanitary significance and its elevated incidence in water sources and sewage samples (Xagoraraki et al. 2007 [22]). The frequency and viral loads found in the present study were higher when compared to previous studies. The occurrence of HAdV by molecular methods in finished drinking water and tap water has been reported worldwide: 39.1\% in South Korea (Lee and Kim 2002 [21]), 52\% in California (USA) (Jiang and Chu 2004 [23]), 12.9\% in Benin (Verheyen et al. 2009 [24]) and 66\% in South Brazil (Rigotto et al. 2010 [25]). The high rates of contaminated mineral water may be a reflection of the overall poor quality of Brazilian groundwater bodies, since the source of water for the commercial brands studied are all from wells and springs located in the southern region of Brazil. In a previous study from 
our group, De Oliveira et al. (2012) [11] found HAdV in up to $23.2 \%$ of water samples from dairy farms, and the majority of the positive samples were from natural springs and groundwater. In Brazil, Rigotto et al. (2010) [25] evaluated chlorinated drinking water and ICC-PCR indicated that 50\% (54/84) were found to be infected with HAdVs. Such high frequency of infectious adenovirus detection in drinking water from these regions is alarming. Studies based on risk analysis, using an adenovirus occurrence rate of 1/100-1/1000 $\mathrm{L}$ in drinking water, indicate an illness rate between 8.3/1000 and $8.3 / 10000$ in drinking water (Jiang 2006 [26]).

In the samples analyzed, there was also incidence of GARV $(25 \%, 10 / 40)$ in the six brands of bottled water used in the study, with the GARV genome present in three (50\%) and absent in the 20 L containers. GARV has been considered to be the major etiological agent of childhood diarrhea in the world, and it has been related to 527,000 deaths annually, mostly in developing countries (Racaniello 2010 [27]). With regard to $\mathrm{hEV}$ detection, this virus was present in low frequency $(17.5 \%)$ when compared to HAdV and GARV. Several authors have reported that simultaneous contamination of water by different enteric viruses is often found (Brassard et al. 2005 [28]; Gilgen et al. 1997 [29]; Fong and Lipp 2005 [5]). In this work, among the six brands surveyed, only one did not present simultaneous contamination (brand F). Brands A and B were contaminated with GARV and HAdV, brand $\mathrm{C}$ and $\mathrm{E}$ with hEV and HAdV and brand $\mathrm{D}$ presented the genome for the three enteric viruses (hEV, GARV and HAdV).

There is a large sanitation deficit in Brazil and only $48.7 \%$ of the population has sewage collection and only $37.9 \%$ of the sewage is treated, ranking Brazil 112th in Sanitation Development Index, which includes 200 countries (SNIS, 2014 [30]). This scenario generates a great impact on the environment due to the large amounts of sewage discharged into the environment without treatment, affecting surface and groundwater sources for public supply and mineral water exploitation. Studies performed in Brazil have already demonstrated the importance of monitoring bottled water quality, however, without any information regarding viral presence (Castro et al. 2010 [31]; Santana et al. 2003 [3]; Silva et al. 2008 [16]; Resende 2008 [14]). Another important aspect to be considered is the fact that the Brazilian regulations serve as references for published research, so the safety parameters must be expanded, thus preserving the health of the population. Until now, there have been very few studies worldwide evaluating viral contaminants in bottled water, even though the scientific community has made great efforts to highlight the significance of these agents regarding the risks populations are exposed to when consuming this product. Product storage is another issue to be discussed, since enteric viruses can easily adhere to polyethylene terephthalate (PET) bottle walls and glass, as shown in a study that intentionally contaminated mineral water in order to evaluate absorption of these agents in PET bottles and glass (Butot et al. 2007 [32]). Regarding water treatments applied to minimize contamination, those are based on chemical (chlorination, ozonation) or physical methods (high temperature). However, according to Brazilian legislation, mineral water cannot receive any disinfection treatment.

Given the above, we consider that bottled water may present potentially questionable microbiological qualities, thus exposing the public to health risks when consumed. We conclude that, in order to minimize disease outbreaks, monitoring mineral water quality is important and relevant, not only with regard to the presence of bacteria, but also the presence of enteric viruses. Due to the increased consumption of bottled water, new standards should be established in order to protect the consumer from waterborne diseases. For most people, mineral water is considered pure and safe and its consumption has grown, benefiting from the fact that there is mistrust of treated water provided by supply systems. 
Silva et al. (2008) [16] has pointed out that there is a cultural tendency to opt for mineral water consumption, to the expense of public water system, because the population perceives groundwater to be of higher quality. Our findings demonstrate severe human fecal origin contamination. Nevertheless, it was not possible to trace the origin of the contamination within the scope of the current study, but we suggest that the contamination may have occurred at the source (water catchments) or from the product's processing or packaging (bottle).

\section{Acknowledgements}

This work was supported by Feevale University, the Coordination for Improvinh Higher Level Personnel (CAPES), and the National Council for Scientific and Technological Development (CNPq).

\section{Author Contributions}

VRS conducted water sampling, concentration and molecular detections, and wrote first draft of the manuscript, CR has compiled all data, wrote and prepare the final version of the manuscript, RS and ADV participated in standardization of molecular techniques and performed molecular assays, AH participated in writing of the manuscript, FRS was responsible of experimental design, general coordination and revised the manuscript.

\section{Conflicts of Interest}

The authors declare that there is no conflict of interest.

\section{References}

1. ABINAM. Associação Brasileira de Indústria de Água Mineral. Available online: http://www.abinam.com.br/home.php (accessed on 29 June 2010).

2. Queiroz, J.T.M.; Doria, M.F.; Rosenberg, M.W.; Heller, L.; Zhouri, A. Perceptions of bottled water consumers in three Brazilian municipalities. J. Water Health 2013, 11, 520-531.

3. Santana, A.S.; Silva, S.C.F.L.; Farani, I.O.J.; Amaral, C.H.R.; Macedo, V.F. Qualidade Microbiológica de Águas Minerais. Food Sci. Technol. 2003, 23, 190-194.

4. BRASIL. Agência Nacional de Vigilância Sanitária. Resolução RDC n 274, de 22 de Setembro de 2005. Aprova o "Regulamento Técnico Para Águas Envasadas e Gelo". Available online: http://portal.anvisa.gov.br/wps/wcm/connect/9b898900474592b89b15df3fbc4c6735/RDC_274_2 005.pdf?MOD=AJPERES\&useDefaultText=0\&useDefaultDesc $=0$ (accessed on 20 November 2011).

5. Fong, T.T.; Lipp, E.K. Enteric viruses of humans and animals in aquatic environments: Health risks, detection, and potential water quality assessment tools. Microbiol. Mol. Biol. Rev. 2005, 69, 357-371

6. Ahmad, M.; Bajahlan, A.S. Quality comparison of tap water vs. bottled water in the industrial city of Yanbu (Saudi Arabia). Environ. Monit. Assess. 2009, 159, 1-14.

7. Gassilloud, B.; Schwartzbrod, L.; Gantzer, C. Presence of viral genomes in mineral water: A sufficient condition to assume infectious risk? J. Med. Med. Sci. 2003, 69, 3965-3969. 
8. Leclerc, H.; Moreau, A. Microbiological safety of natural mineral water. FEMS Microbiol. Rev. 2002, 26, 207-222.

9. Katayama, H.; Shimasaki, A.; Ohgaki, S. Development of a virus concentration method and its application to detection of enterovirus and norwalk virus from coastal seawater. Appl. Environ. Microbiol. 2002, 68, 1033-1039.

10. Vecchia, A.D.; Fleck, J.D.; Comerlato, J.; Kluge, M.; Bergamaschi, B.; Silva, J.V.S.; da Luz, R.B.; Teixeira, T.F.; Garbinatto, G.N.; Oliveira, D.V.; et al. First description of Adenovirus, Enterovirus, Rotavirus and Torque teno virus on water samples collected from the Arroio Dilúvio, Porto Alegre, Brazil. Braz. J. Biol. 2012, 72, 323-329.

11. De Oliveira, L.K.; Fleck, J.D.; Comerlato, J.; Kluge, M.; Bergamaschi, B.; Fabres, R.B.; da Luz, R.B.; da Silva, J.V.S.; Rodrigues, M.T.; Genro, J.L.; et al. Enteric viruses in water samples from Brazilian dairy farms. Agric. Water Manag. 2012, 111, 34-39.

12. Dalla Vecchia, A.; Rigotto, C.; Staggemeier, R.; Soliman, M.C.; Gil de Souza, F.; Henzel, A.; Santos, E.L.; do Nascimento, C.A.; de Quevedo, D.M.; Fleck, J.D.; et al. Surface water quality in the Sinos River basin, in Southern Brazil: Tracking microbiological contamination and correlation with physicochemical parameters. Environ. Sci. Pollut. Res. 2015, 22, 9899-9911.

13. Wolf, S.; Hewitt, J.; Greening, G.E. Viral multiplex quantitative PCR assays for tracking sources of fecal contamination. J. Appl. Microbiol. 2010, 76, 1388-1394.

14. Resende, A. Perfil microbiológico da água mineral comercializada no Distrito Federal. SaBios Rev. Saúde e Biol. 2008, 3, 16-22.

15. Ritter, A.C.; Tondo, E.C. Avaliação microbiológica de água mineral natural e de tampas plásticas utilizadas em uma indústria da grande Porto Alegre/RS. Aliment. Nutr. 2009, 20, 203-208.

16. Silva, M.E.Z.; Santana, R.G.; Guilhermetti, M.; Camargo Filho, I.; Endo, E.H.; Ueda-Nakamura, T.; Nakamura, C.V.; Dias Filho, B.P. Comparison of the bacteriological quality of tap water and bottled mineral water. Int. J. Hyg. Environ. Health 2008, 211, 504-509.

17. Rosa, S.P.; Silva, S.R.P.; Mann, M.B.; Corção, G. Avaliação da presença de coliformes totais e fecais em amostras de água mineral comercializadas em Porto Alegre-RS. Rev. Hig. Aliment. 2008, 22, 94-99.

18. Zeenat, A.A.; Hatha, M.; Viola, L.; Vipra, K. Bacteriological quality and risk assessment of the imported and domestic bottled mineral water sold in Fiji. J. Water Health 2009, 7, 642-649.

19. Pontara, A.V.; de Oliveira, C.D.D.; Barbosa, A.H.; dos Santos, R.A.; Pires, R.H.; Martins, C.H.G. Microbiological monitoring of mineral water commercialized in Brazil. Braz. J. Microbiol. 2011, 42, 554-559.

20. Beuret, C.; Kohler, D.; Baumgartner, A.; Lüthi, T.M. Norwalk-Like virus sequences in mineral waters: One-year monitoring of three brands. Appl. Environ. Microbiol. 2002, 68, 1925-1931.

21. Lee, S.H.; Kim, S.J. Detection of infectious enteroviruses and adenoviruses in tap water in urban areas in Korea. Water Res. 2002, 36, 248-256.

22. Xagoraraki, I.; Kuo, D.H.W.; Wong, K.; Wong, M.; Rose, J.B. Occurrence of Human Adenoviruses at Two Recreational Beaches of the Great Lakes. Appl. Environ. Microbiol. 2007, 73, 7874-7881.

23. Jiang, S.C.; Chu, W. PCR detection of pathogenic viruses in southern California urban rivers. J. Appl. Microbiol. 2004, 97, 17-28. 
24. Verheyen, J.; Timmen-Wego, M.; Laudien, R.; Boussaad, I.; Sen, S.; Koc, A.; Uesbeck, A.; Mazou, F.; Pfister H. Detection of Adenoviruses and Rotaviruses in Drinking Water Sources Used In Rural Areas of Benin, West Africa. Appl. Environ. Microbiol. 2009, 75, 2798-2801.

25. Rigotto, C.; Victoria, M.M.; Moresco, V.; Kolesnikovas, C.K.M.; Corrêa, A.A.; Souza, D.S.M.; Miagostovich, M.P.; Simões, C.M.; Barardi, C.R. Assessment of adenovirus, hepatitis A virus and rotavirus presence in environmental samples in Florianopolis, South Brazil. J. Appl. Microbiol. 2010, 109, 1979-1987.

26. Jiang, S.C. Human Adenoviruses in Water: Occurrence and Health Implications: A Critical Review. Environ. Sci. Technol. 2006, 40, 7132-7140.

27. Racaniello, V. Virology Blog. Porcine Circovirus DNA in Rotavirus Vaccine. Available online: http://www.virology.ws/2010/03/22/porcine-circovirus-dna-in-rotavirus-vaccine/ (accessed on 23 April 2013).

28. Brassard, J.; Seyer, K.; Houde, A.; Simard, C.; Trottier, Y.L. Concentration and detection of hepatitis A virus and rotavirus in spring water samples by reverse transcription-PCR. J. Virol. Methods 2005, 123, 163-169.

29. Gilgen, M.; Germann, D.; Luthy, J.; Hubner, P.H. Three-step isolation method for sensitive detection of enterovirus, rotavirus, hepatitis A virus, and small round structured viruses in water samples. Int. J. Food Microbiol. 1997, 37, 189-199.

30. SNIS, 2014. The National Information System on Sanitation. Available online: http://www.snis.gov.br (accessed on 20 December 2014).

31. Castro, L.R.S.; Carvalho, J.S.; Vale, V.L.C. Avaliação microbiológica de diferentes marcas de água mineral. Rev. Bras. Saúde Pública 2010, 34, 835-844.

32. Butot, S.; Putallaz, T.; Croquet, C.; Lamothe, G.; Meyer, R.; Joosten H.; Sánchez, G. Attachment of enteric viruses to bottles. Appl. Environ. Microbiol. 2007, 73, 5104-5110.

(C) 2015 by the authors; licensee MDPI, Basel, Switzerland. This article is an open access article distributed under the terms and conditions of the Creative Commons Attribution license (http://creativecommons.org/licenses/by/4.0/). 